\title{
Automation and Optimal Capital Income Taxation
}

\author{
Yuuki Maruyama
}

\begin{abstract}
This model shows that capital income taxation does not affect real wages. Judd's theorem (1985) that a zero capital income tax rate is optimal for workers is based on the assumption that all capital has the effect of increasing the marginal productivity of labor. However, in reality, some capital lowers the marginal productivity of labor through automation (technological unemployment). Therefore, this model assumes two types of capital. Labor-complementing capital increases the marginal productivity of labor (real wages), while labor-substituting capital decreases it. The rates of return are kept equal between the two. Using such an economic growth model, we analyze the long-run effects of taxes on real wages. Even if capital income tax is imposed, real wages don't change because both labor-complementing capital and labor-substituting capital decrease. In contrast, value-added tax results in reduced real wages. This is because labor costs are deducted in capital income tax, but not in value-added tax. Capital income tax is more suitable for income redistribution than value-added tax. These conclusions also apply to an open economy.
\end{abstract}

(JEL Classification: E22, E24, E25, H21, H22, H23, J23, O14, O31, O33)

資本所得課税が実質賃金に影響を与えないようなモデルを示す。労働者にとって最適な資本 所得税率はゼロであるという Judd(1985)の理論は、資本には労働の限界生産性を増加させる 効果があるという仮定に基づいている。しかし現実においては、資本は機械化を通して労働者 の仕事を奪い、労働の限界生産性を低下させる場合もある。そのため、このモデルにおいては 資本を 2 種類に分類する。労働補完的な資本は労働の限界生産性（実質賃金）を増加させるの に対し、労働代替的な資本は労働の限界生産性を低下させるものとする。それぞれへの投資は 利益率が均衡するように行われることになり、利益率が等しい状態を保ちながらそれぞれの 資本は増加していく。このようなモデルを用いて、税が実質賃金に与える長期的影響について 分析を行う。資本所得課税を行っても、労働補完的な資本と労働代替的な資本の両方が減少す ることになるため、実質賃金は変化しないことが示される。対照的に、付加価值税を行う場合 は実質賃金が低下寸ることが示される。この違いは、資本所得税においては収益から労働者の 人件費が損金として控除されるのに対し、付加価值税においては損金扱いにならないことに 起因している。所得再分配には付加価值税よりも資本所得税が適していることがこのモデル から示される。これらの結論は開放経済においても成立する。 


\section{1 序論}

最適税率に関しては多くの理論が存在している。特に資本所得課税の最適税率について は Judd(1985)の研究が有名である。この理論においては、資本には労働者の限界生産性を 増加させる効果があると仮定しており、資本所得課税を行うと資本の供給量が減少するた め、労働者の限界生産性も減少することになる。そのため、賃金と再分配の効果を合わせて 考えると、資本所得税の最適税率は $0 \%$ あるという結論が得られている。

しかし現実の経済においては、資本は必ずしも労働者の限界生産性を増加させるわけで はない。確かに、増産設備の構築などの設備投資は労働者の限界生産性を増加させるが、AI の発達や作業の機械化などについては逆に労働者の限界生産性を低下させることがある

（後者のような資本が増加する場合、賃金が完全に伸縮的であれば賃金の低下という形で 現れ、賃金が伸縮的でなければ失業率の上昇という形で現れることになる)。

そのため、資本を 2 種類に分けて考えることが重要であると考えられる。Acemoglu(2018) においても、タスクの観点から資本を 2 種類に分けて扱い、自動化による失業についてモ デル分析がなされている。今回のモデルにおいては、労働者の限界生産性を高める資本を労 働補完的資本、労働者の限界生産性を下げる資本を労働代替的資本と呼ぶことにする。資本 家が合理的に投資行動を行うなら、両資本は利益率の均衡を保ちながら増加していくこと になる。このような条件の下で資本が増加していく場合に、賃金はどのように変化していく かについてまず分析を行う。また、資本所得税や付加価值税を実施した場合に賃金がどのよ うな影響を受けるかについても分析を行う。

\section{2 モデル}

1 つの生産関数で労働代替的資本と労働補完的資本の 2 つを扱うのは難しいため、今回の モデルにおいては 2 つ生産関数を想定する。生産関数 1 で労働代替的資本を扱い、生産 関数 2 で労働補完的資本を扱う。モデルは一財モデルとし生産する財の種類は両部門で同 じであるとするが、生産関数は異なるという形になる。また、両部門の間で労働者や資本の 移動はスムーズであるとし、賃金や利益率は均衡することになる。

$Y_{i}$ を生産量、 $L_{i}$ を雇用量、 $K_{i}$ を資本の量、 $A_{i}$ を生産性として、2 つの生産関数は以下のよう に表される。 $(i=1,2)$

$\alpha, \beta, \gamma$ は定数であり、 $0<\alpha<1,0<\beta<1, \quad 0<\gamma<1$ とする。

$Y_{1}, Y_{2}$ は共に CES 型生産関数ではあるが、 $Y_{1}$ は資本が増えるにつれ労働の限界生産性が低 
下寸るのに対し、 $Y_{2}$ は資本が増えるにつれ労働の限界生産性が上昇することが分かる。（労 働代替的資本を扱うために便宜上 $Y_{1}$ は規模に対して収穫派減な生産関数としている)

労働の総供給量を $L$ 、資本の総供給量を $K$ とする。 $L$ は賃金 $w$ の単調増加関数とし、 $K$ は利 益率 $r$ の単調増加関数とする。

$$
\begin{aligned}
& L_{1}+L_{2}=L \\
& K_{1}+K_{2}=K
\end{aligned}
$$

付加価值税の税率を $T$ とし、資本所得税の税率を $t$ とすると、各部門の資本所得 $R_{i}$ は

$$
\begin{aligned}
& R_{1}=(1-t)\left\{(1-T) Y_{1}-w L_{1}\right\} \\
& R_{2}=(1-t)\left\{(1-T) Y_{2}-w L_{2}\right\}
\end{aligned}
$$

となる。

各部門では $R_{i}$ を最大化するように雇用量を決定することになる。よって、

$$
\frac{\partial R_{1}}{\partial L_{1}}=0 \quad \frac{\partial R_{2}}{\partial L_{2}}=0
$$

となる。労働者の税引き後の限界生産性が均衡賃金 $w$ と等しくなるまで雇用を行うことに なる。

また、両産業で利益率が均衡するため、

$$
\frac{\partial R_{1}}{\partial K_{1}}=\frac{\partial R_{2}}{\partial K_{2}} \quad(=r)
$$

となる。（賃金と利益率の扱い方の非対称性は、資本家が労働者の雇用数を決定するという 仮定によるものである)

これを解くと、

$$
\begin{gathered}
w=(1-T) A_{2} \beta^{\beta}\left(\frac{\alpha(1-\beta)}{1-\alpha}\right)^{1-\beta} \\
r=(1-t)(1-T) A_{2}(1-\beta)\left(\frac{\beta(1-\alpha)}{\alpha(1-\beta)}\right)^{\beta}
\end{gathered}
$$

となる。（計算過程については Appendix 参照）

まず、資本供給量 $K$ は賃金に影響を与えないことが分かる。これは、 $K$ が増加していく にあたっては、労働代替的資本と労働補完的資本の両者が利益率を均衡させながら増加し ていくためである。このメカニズムについて述べる。労働代替的資本への投資が行われると、 それにより一時的に貨金は下がる。すると人件費が下がることで、労働代替的資本への投資 よりも労働補完的資本への投資の方が利益率は高くなる。そのため、労働補完的資本への投 資の方が多く行われるようになり、賃金は元の水準まで回復する。このような原理により、 
賃金は資本供給量 $K$ に依存せずに決まることになるわけである。言い換えると、このモデ ルによれば、機械化が進んでも雇用が失われたり賃金が減少したりはしないことになる。こ の結論はAcemoglu(2018)のモデルでの結果とも合致する。

また、付加価值税 $T$ は賃金を低下させるが、資本所得税 $t$ は賃金に影響を与えないことが 分かる。この原理について述べる。資本所得税と付加価值税のじちらを行う場合でも投資の 利益率は低下寸ることになるため、投資のインセンティブは減少し、資本の供給量 $K$ は減 少することになる。しかし先ほじ述べたように、労働代替的資本と労働補完的資本の両方が 減少することになるため、資本の供給量 $K$ の低下自体は賃金には影響しない。ただ、付加価 值税の場合は人件費が控除されないため、労働者の税引き後の限界生産性が減少すること になり、賃金は低下してしまう。それに対して、資本所得税は人件費が控除されるため、労 働者の税引き後の限界生産性は変化せず、賃金も変化しないことになる。この結果について は、賃金 $w$ は $K$ の值によらずに決まることより、動学的にも当てはまる結果であることが 分かる。つまり、動学的な結論として、所得再分配には資本所得税の方が適していると言え る。また同様の理由で、本結論は閉鎖経済だけでなく開放経済においても成り立つことが分 かる。開放経済において資本所得課税を行うと、その国から他の国へと資本逃避が起こるが、 労働補完的資本と労働代替的資本の両方が資本逃避するため、結果としてその国における 賃金水準は影響を受けないことになる。

\section{3 結論}

今回のモデルでは、税による所得再分配について分析を行った。既存の租税理論は労働補 完的資本のみを考えるものがほとんどであり、資本所得税は労働者の賃金を低下させると いう結論となっていた。今回の論文では労働補完的資本だけでなく労働代替的資本を考慮 して分析することで、資本所得課税が賃金に影響しないようなモデルを示した。所得再分配 に関して、既存の租税理論では付加価值税の方が有用とされてきたが、今回のモデルでは資 本所得税の方が有用であるという対照的な結論が得られたことになる。

より多様な生産関数を用いて今回のような分析を行い、結論が変化しうるかについて分 析することが今後の課題の一つである。 


\section{Appendix}

$w$ や $r$ を求める計算について述べる。

$$
\begin{gathered}
\frac{\partial R_{1}}{\partial L_{1}}=(1-T) A_{1} \alpha \gamma\left\{\alpha L_{1}+(1-\alpha) K_{1}\right\}^{\gamma-1}-w \\
\frac{\partial R_{1}}{\partial K_{1}}=(1-t)(1-T) A_{1}(1-\alpha) \gamma\left\{\alpha L_{1}+(1-\alpha) K_{1}\right\}^{\gamma-1}
\end{gathered}
$$

より

$$
\frac{\partial R_{1}}{\partial L_{1}}=\frac{\alpha}{(1-t)(1-\alpha)} \frac{\partial R_{1}}{\partial K_{1}}-w
$$

であることが分かる。また、生産関数 2 についても計算すると、

$$
\begin{gathered}
\frac{\partial R_{2}}{\partial L_{2}}=(1-T) A_{2} \beta L_{2}^{\beta-1} K_{2}^{1-\beta}-w \\
\frac{\partial R_{2}}{\partial K_{2}}=(1-t)(1-T) A_{2}(1-\beta) L_{2}^{\beta} K_{2}^{-\beta}
\end{gathered}
$$

となる。

(1)〜 (5)より、

$$
\frac{K_{2}}{L_{2}}=\frac{\alpha(1-\beta)}{\beta(1-\alpha)}
$$

(1), (4), (6) より

$$
w=(1-T) A_{2} \beta^{\beta}\left(\frac{\alpha(1-\beta)}{1-\alpha}\right)^{1-\beta}
$$

(2), (5), (6) より

$$
r=(1-t)(1-T) A_{2}(1-\beta)\left(\frac{\beta(1-\alpha)}{\alpha(1-\beta)}\right)^{\beta}
$$

となる。

また、本モデルを解くと、資本の蓄積により総資本量 $K$ が大きくなるほど、 $K_{1}, K_{2}, L_{2}, \frac{K_{2}}{K}$ は増加し、 $L_{1}, \frac{K_{1}}{K}$ は減少することが分かる。経済成長に伴い、労働補完的資本の割合が増加 していくことになる。

加えて、労働者人口が増え $L$ が大きくなるほど、 $L_{1}, L_{2}, K_{2}, \frac{L_{2}}{L}$ は増加し、 $K_{1}, \frac{L_{1}}{L}$ は減少する ことも分かる。労働者人口が増加するほど、労働代替的資本は減少し、労働代替的な企業の 雇用割合も減少するわけである。 


\section{References}

Acemoglu, D., \& Restrepo, P. (2018). The race between man and machine: Implications of technology for growth, factor shares, and employment. American Economic Review, 108(6), 1488-1542.

Chamley, C. (1986). Optimal taxation of capital income in general equilibrium with infinite lives. Econometrica: Journal of the Econometric Society, 607-622.

Judd, K. L. (1985). Redistributive taxation in a simple perfect foresight model. Journal of public Economics, 28(1), 59-83. 